\title{
The Role of Critical Thinking in Helping Students Cope with Problems
}

\author{
Violla Makhzoum $^{2}$, Lama Komayha ${ }^{3}$, Mazen Jabbour ${ }^{4}$ \\ ${ }^{1}$ Lecturer, Islamic University of Lebanon, Lebanon \\ ${ }^{1}$ Lecturer, Islamic University of Lebanon, Lebanon \\ ${ }^{1}$ Statistics, Lebanon
}

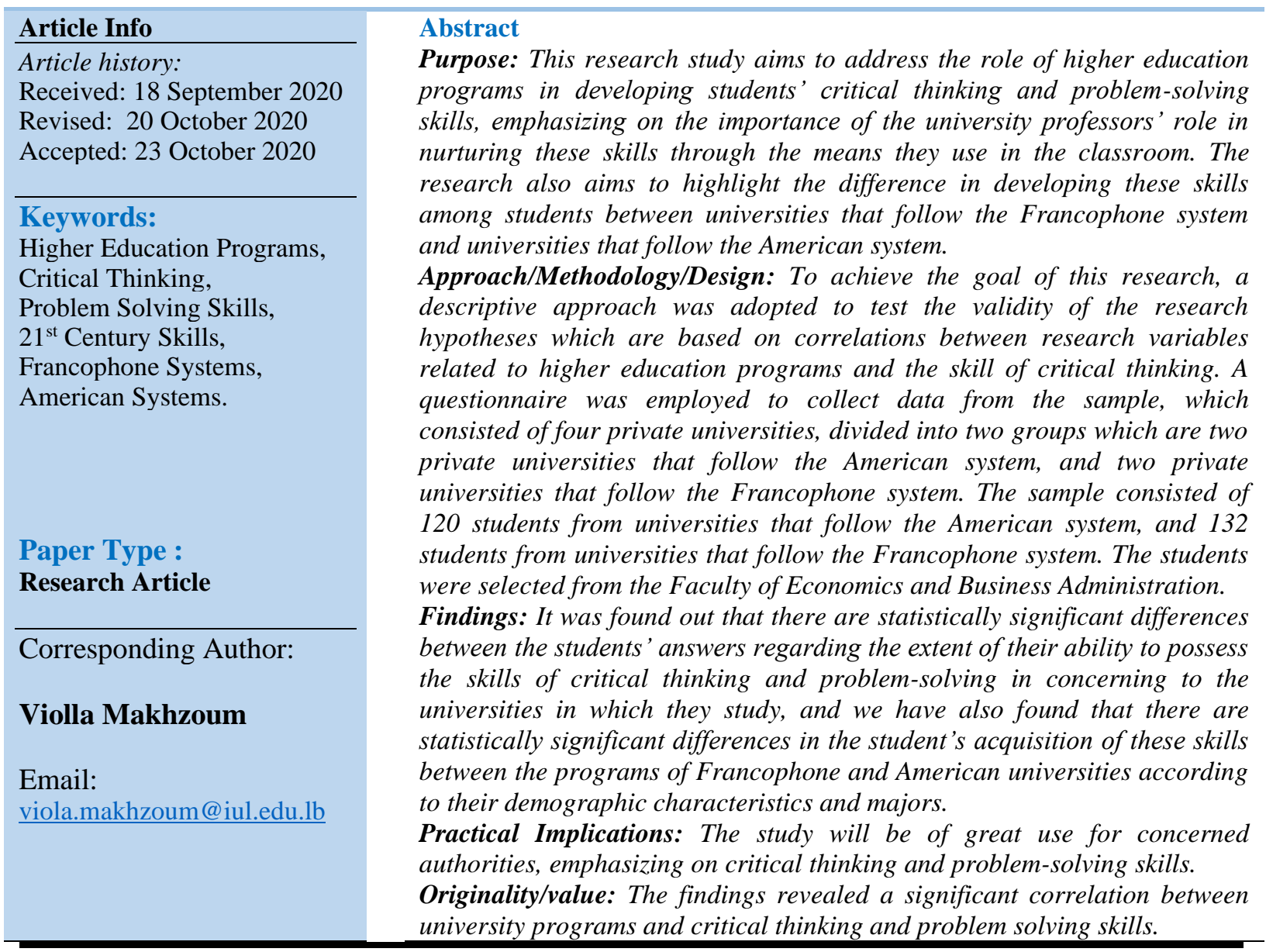

\section{Introduction}

The twenty-first century is characterized by many developments in all aspects of human life, in terms of knowledge, technology, and education, as well as life skills. Today, we live in an era of cognitive, economic, and technological competition among countries (Trilling \& Fadel, 2013). This competition is obliging organizations to search for employees who have skills that enable them to communicate with others via modern technologies. These skills are called the twenty-first-century skills, which were defined by Trilling \& Fadel (2013, p.41) as "a set of skills necessary for success and work in the twenty-first century, such as learning and 
innovation skills, information and media skills, technology and culture skills, and life and work skills".

In the current twenty-first century, many challenges are posed for humanity. These challenges could be categorized as environmental, economic, political, social, educational, and others. Some examples include climate changes, the emergence of new diseases and epidemics, as well as other challenges at personal levels. It has become a major challenge nowadays for people to find a job that stimulates their aspirations and contributes to their happiness and stability at the same time. To keep pace with this rapidly changing and highly complex environment, there are many skills that allow the individual to deal with all the transformations previously mentioned, knowing that these skills are not only the result of this century (Trilling \& Fadel, 2009). Rather, it is an extension of the basic skills that the individual possessed in the past, with the accumulation of other new skills and competencies that enable individuals to live more efficiently in this demanding era.

This century, which depends on knowledge and its economy, requires preparing generations of learners who have the skills necessary to discover, use, participate in, and add to the current knowledge. This can only be achieved through educational institutions, especially higher education institutions. Therefore, higher education and in light of all these requirements is facing major challenges, as it is the ideal place "to absorb science and technology, raise skills and professional competencies, and develop society to become a community of knowledge so that it can compete in the global labor market" (UNESCO, 2012), especially since continuous learning is the required and irreplaceable formula for everyone to succeed.

Based on the foregoing, the university is considered one of the major institutions of education and upbringing in society and is seen as the highest level of the pyramid in the education system (Browen \& All, 2005). Moreover, the "university" has witnessed many developments and changes in concept and organization, and it has acquired with time a set of features such as being a fundamental place of mental excellence, thought education, and objective knowledge. It is also considered a place to produce knowledge for itself and transfer it to those who can absorb it and benefit from it (Boud \& Hager, 2012). The country's economy depends on the quality of higher education because its institutions provide the labor market with graduates that are supposed to have been armed with twenty-first-century skills. Besides, because higher education is an institution that combines experiences, knowledge, and skills, it also bears the responsibility of preparing generations to serve the society in all branches of science, professions, and skills. Higher educational institutions vary to include universities, colleges, and institutes. The universities also contribute to forming the students' personality, building knowledge and behavioral knowledge, and enabling them to rely on themselves, and taking independent personal decisions wisely and logically. Here we do not mean independence, i.e. absolute individualism, but rather enhancing self-confidence, not relying on others, and extracting dependency values. One of the consciences also is to lead students to have creative initiatives that are the basic criterion in university work. 
The current era requirements impose on all forms of organizations to possess a human capital with competencies of distinct knowledge, skills, and capabilities, and at a high level of creativity and ability to respond quickly to the necessities of change. These competencies should allow higher education institutions to survive and compete through excellence. From here on, higher education institutions must find the best ways to invest and develop the human mind and exploit these human energies towards access to creativity, creative innovation, and the adoption of sophisticated technology. The problem started to take shape through several reports around the world (Schleicher, 2012) confirming that the "skills gap of the twenty-first century" is costing the business sector large amounts of money to find skilled workers, employ them, and train new employees to match the required standards (Gordon, 2013). The enhancement of the competencies of the twenty-first century is a gradual process that can only be achieved through advanced education systems. Accordingly, the Organization for Economic Cooperation and Development (2015) conducted many studies to follow up on the development of key competencies, and results showed that educational systems in the twenty-first century must help students in developing suitable skills and competencies for individual development and social progress. Besides, results also indicated the existence of a gap between the new jobs market and the skills that individuals have (Koske \& All, 2015).

The research problem is determined in the transformations of the twenty-first century and the digital control it imposes on all aspects of life, which can only be dealt with by acquiring many skills and competencies necessary for individuals to participate in a rapidly moving society and changes. Studies linking higher education with the skills of the twenty-first century were very few at the local level, which prompted us to search for the role that higher education plays in providing students with critical thinking and problem-solving skills in Lebanon.

The research aims to study the correlation between higher education programs and students' critical thinking and problem-solving skills. We chose these skills due to their importance in this era. Moreover, the thinking process includes multiple steps and processes that could be followed to solve an upcoming problem through the use of inductive and deductive inference. The following visual clarifies the importance of critical thinking:

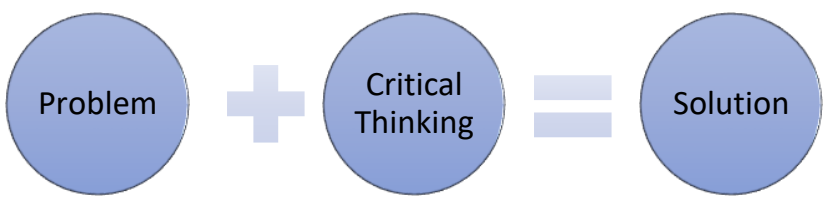

Figure 1: The Role of Critical Thinking

The guiding questions in this research study are formulated below:

- What is the relationship between higher education programs and providing critical thinking and problem-solving skills to students? 
- What role does the teacher play in providing students with critical thinking and problem-solving skills?

- Are there statistically significant differences between university programs that follow the French system (Francophone) and universities that follow the American system in providing students with critical thinking and problemsolving skills?

The researchers also formulated certain hypotheses:

- There is a statistically significant correlation between higher education programs and the students' acquisition of critical thinking and problemsolving skills.

- There is a statistically significant correlation between the teaching practices in the classroom and the student's acquisition of critical thinking and problem-solving skills.

- There are statistically significant differences between university programs that follow the French system (Francophone) and university programs that follow the American system in terms of providing students with critical thinking and problem-solving skills.

\section{Literature Review}

The Greek philosopher Aristotle believed that "the learner's mind is in his ability to comprehend the idea without accepting it" (Edgar, 2012). Theories of psychology have developed general frameworks to explain the dynamics of complex human behaviour to understand it through notions and principles. These principles are a summary of what scholars have reached in the field of human behaviour and its nature (Carver \&Scheier, 2012). Therefore, it is important to present the major theories that attempt to show a clear picture of understanding the nature of thinking in general and critical thinking in particular in an organizational framework that works to express information and facts in the form of laws (Bean, 2011).

Facione (2011) discussed the most prominent theories that explained critical thinking in their book "The Chain of Thinking and its Patterns". We presented a summary of their discussion:

\subsection{Bloom's Taxonomy Theory (1956):}

Bloom ranked the levels of human thinking into six levels (knowledge, understanding, application, analysis, synthesis, and evaluation) (seaman, 2011). This classification begins with the basic operations, and then gradually takes on to reach higher levels of complexity. Critical thinking according to Bloom's classification occupies three cognitive levels (analysis, synthesis, and evaluation), and all these processes are key requirements for success in any subsequent process.

- Analysis: It is the ability to analyze the idea to its basic elements, parts, and components, and discover relationships between them. It is a complex process because it requires a set of skills to reveal the connections between facts. Critical 
thinking cannot be launched if it has not been preceded by a careful analysis of the situation (Add Reference).

- Synthesis: It is the process of organizing elements and parts and linking them together to form a model or structure that did not previously exist.

- Evaluation: it is the ability to make judgments for the measured feature in light of a given standard, and this level is considered one of the paramount levels in Bloom's classification.

Bloom believed that the success of critical thinking depends on the effectiveness of the three previously mentioned processes.

\subsection{Guilford's Theory (1959):}

Guilford (1959) believed that critical thinking is an evaluation process in which the critical and final aspects of the thinking process are represented, and according to this sense, it is the conclusion of the processes of memory, understanding, and deduction. It is also an evaluation process that defines a special standardized process that takes place in the light of Criteria motors. Besides, Guilford found fit for the binary division that Bloom developed to distinguish between the evaluation that depends on internal criteria and the one that depends on external criteria, and in 1972 he proposed the hierarchical pattern of the mind model (Negrini, 2018).

\subsection{Piaget's Theory (1956)}

Piaget investigated the role of the interrelationship between neurological preparations and environmental experiences in the frameworks of child intelligence and the development of his ability to use logic. He looked at cognitive development from two angles, the mental structure, and mental functions, so that cognitive development cannot take place without them. It is worth noting that Piaget did not use the word critic in his discussions about mental processes, but there is a clear similarity between his intellectual or abstract classification and what is known as critical thinking. That is, the ability to form generalizations and enjoy the use of new possibilities and reject prejudices on matters. Piaget is known to be the best of those who presented an integrated theory of cognitive development, and he divided it into four stages (Beilin \&Pufall, 2013):

- Sensor motor stage: birth to 2 years

- Preoperational stage: ages 2 to 7

- Concrete operational stage: ages 7 to 11

- Formal operational stage: ages 12 and up

According to Piaget, we can form a perspective of abstract thinking by looking at the third and fourth stages of mental development stages. Although Piaget's theory indicates that the child at the age of seven and twelve is able to understand the concepts of memorization and begins using some logical processes, and although he/she can learn some tools of logical 
thinking, he finds it difficult to deal with abstract ideas. However, in the last stage, he/she can develop the starting capabilities from a world of sensory experiences to abstract understanding, and transfer his focus from concrete facts to a world of possibilities where one can think, construct hypotheses, and provide perceptions of alternatives; and this ability is the core of the critical thinking process.

\subsection{Richard Paul's theory (1984):}

Paul (1984) believed that there is a natural tendency for learners to take the views of others into account, so it is necessary to work continuously to overcome this tendency. Elder (2013) described Paul's ideas about critical thinking:

It is human nature to think (that thinking pervades every aspect of human life and every dimension of the human mind). Though it is human nature to think, it is not natural for humans to think well (human nature is heavily influenced by prejudice, illusion, mythology, ignorance, and selfdeception). Therefore we need to be able to intervene in thinking, analyse, assess, and where necessary, improve it (Stoddard \& All, 2013, p.48).

Paul (1984) believed that critical thinking frees the individual from cases of inability to perceive the views of others, and it also gives room for him to make hypotheses that examine opinions and ideas opposing his views. He categorized learners into three groups:

- Critical thinkers: they are distinguished logical people with high thinking skills.

- Selfish thinkers: people who follow a weak path of thinking in which they are centred on themselves and focus on achieving their interests by manipulating the thoughts of others and controlling their emotions.

- Non-critical thinkers: people who have weak skills, and it is easy for others to deceive and control them.

Therefore Paul (1984) believed that the capabilities of critical thinking are developmental, that is, they grow with age. They begin to appear among learners at the age of (11-12 years) and keep on developing until the learner reaches adulthood and becomes almost mature. It is also a major requirement for all groups of society because it makes the individual independent in his thinking and able to make sound decisions in his life. According to Paul (1984) critical thinking is not just thinking, but it is a necessity that improves the quality of thinking and creates standards for reasoning. Reasoning happens when we impose discipline on our thinking through mental criteria to elevate it to the level of perfection and quality, which can be available in spontaneous uncontrolled thinking (Paul, 1984).

\subsection{Robert Ennis Theory (1985):}


Ennis (1985) is one of the leaders of critical thinking research. He defined it as the type of thinking that deals with what must be believed or done in a situation or event, and it has two main characteristics:

- It is mental thinking in the sense that it leads to valid conclusions and decisions justified or supported acceptably.

- It is contemplative thinking in which there is full awareness of the steps of thinking that leads to conclusions and decisions, and it requires decisions about what must be believed or done.

Ennis (1985) believed that the capabilities of critical thinking are clearer, broader, and more comprehensive than the higher mental capabilities, which include analysis, synthesis, and evaluation according to Bloom's classification of educational goals. Moreover, critical thinking adds to these capabilities the ability to observe and interpret. For this reason, critical thinking skills are more suitable for application in secondary classes and higher education. According to Ennis (1985), the critical thinking process passes in three stages:

- Definition and Clarification: It includes the ability to define the problem and formulate questions about it, and the ability to formulate hypotheses to solve it, and the ability to determine conclusions.

- Information Judgment: It includes the ability to determine the credibility of the observations and basic information related to the subject, and to distinguish them from the less relevant information. So it is the stage of checking and examining the information.

- Drawing Conclusions: It includes the ability to solve the problem, forecast and judge the quality of inductive results, and the validity of the inferences.

\subsection{Bayer theory (1985):}

Beyer (1985) believed that critical thinking refers to the multifaceted process that includes the interaction of knowledge, skill, and direction. Knowledge in this context includes the individuals' understanding of the sources of information related to the field they are dealing with. This knowledge includes experience, knowledge of the opinions of others, and knowledge of the subject matter, which together constitutes an aspect of the ability to think critically (Bayer \& Morrison, 1988). The skill in this context refers to the processes that help the individual to structure, organize, and evaluate information.

Bayer (1985) believed that the skills of solving problems and making decisions are more comprehensive than critical thinking since they are two strategies, each of which consists of a set of processes that the individual follows sequentially. As for critical thinking, it is a group of operations that take place simultaneously, and it is more complicated than basic thinking skills. Critical thinking is not synonymous with making decisions or solving problems; the reason is that it begins with a claim or a specific result depending on its importance and accuracy. Bayer (1985) also believed that critical thinking skills enable us to possess and 
understand information without taking into account the time or place, or the type of information required.

\section{Methodology and Procedures}

We adopted a descriptive research methodology in this research. The descriptive component of the curriculum is based on focusing on the available references that address the topics of the study, especially the references that discussed critical thinking and problem-solving skills (theoretical and empirical studies contained in scientific references, studies, and reports issued by multiple bodies). We also relied on a quantitative research method (questionnaire) in collecting and analysing the field data. According to Gay (2012, p.630) "Quantitative research is the collection of numerical data to explain, predict and/or control phenomena of interest". We used a questionnaire that was administered to a sample of 252 students of private universities which was our target population. Moreover, we abided by the ethical standards of scientific research by respecting the rights and opinions of others and keeping them anonymous. The participants were also informed that their answers will remain confidential.

\subsection{Sample:}

This research was applied to a purposeful sample of private universities in Lebanon. Purposeful sampling is useful in cases where we want to reach directly to the concerned individuals and target groups in the research. We selected two colleges from each university: Educational Sciences\& Economic Sciences.

\subsection{Validity and Reliability:}

To ensure the validity and reliability of the questionnaire, we used the CronbachAlpha Test. Dornyei (2003) mentioned that "somewhat lower Cronbach Alpha coefficients are to be expected, but even with short scales of 3-4 items, we should aim at reliability coefficients in excess of 0.70; if the Cronbach Alpha of a scale does not reach 0.60, this should be warning bells" (Dornyei, 2003, p. 112). The Cronbach Alpha value of the students' questionnaire was 0.82 as shown in Table 1.

Table 1: Cronbach Alfa of Students' questionnaire

\begin{tabular}{cc}
\hline Reliability Statistics & Cronbach Alpha \\
Items & 0.82 \\
252 &
\end{tabular}

Source: Authors

\subsection{Findings:}


The questionnaires were distributed in the French Universities as it follows:

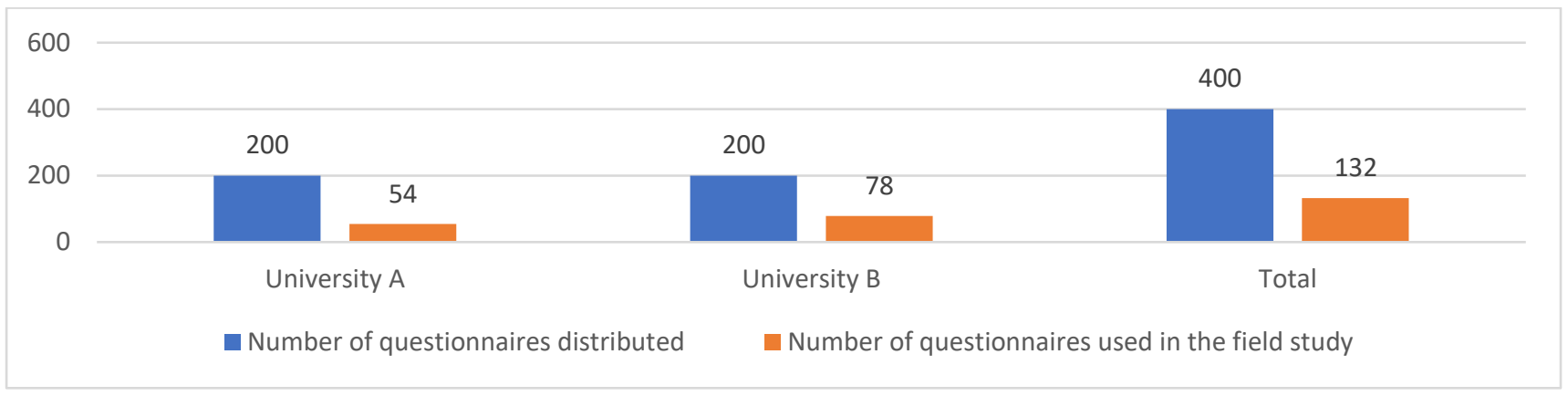

Figure 2: Questionnaires' Distribution in French Universities.

As for the universities that follow the French programs, the questionnaires were distributed as mentioned in figure 2 .

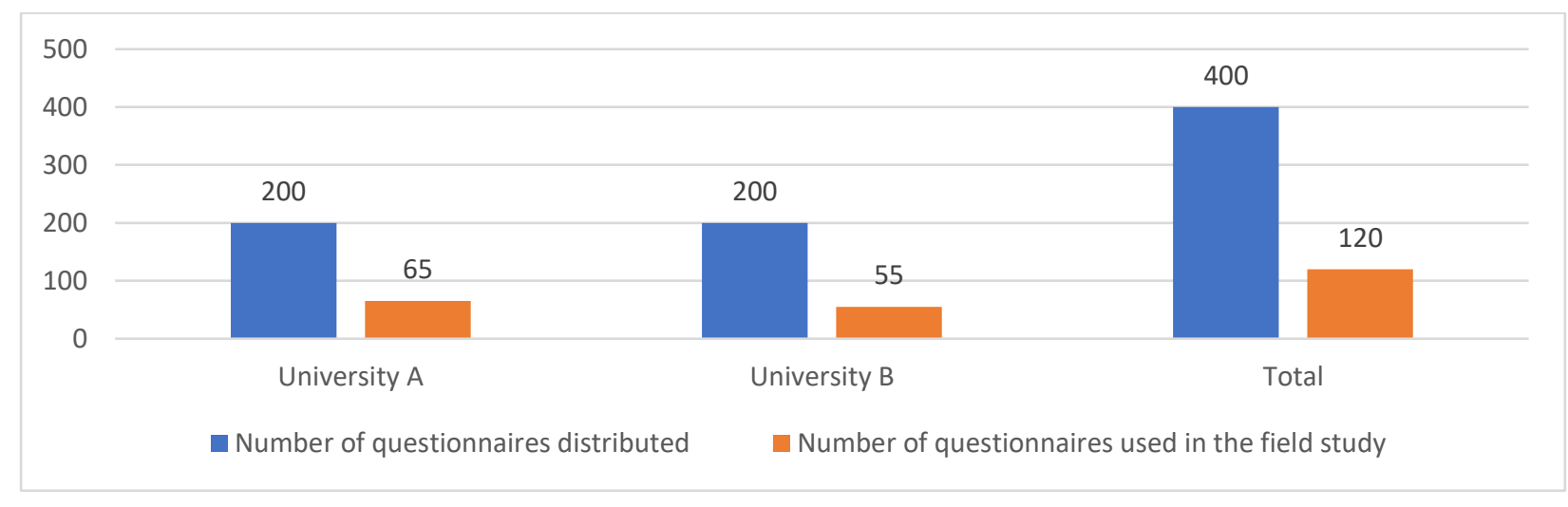

Figure 3: Questionnaires' Distribution in English Universities.

As for the universities that follow the English programs, the questionnaires were distributed as mentioned in figure 3 .

\section{Results and Discussion}

A priority to our research is collecting the necessary data and then tabulating, analyzing, and interpreting it in a scientific way that leads to answering the questions raised in the introduction of this research, and also accepting or rejecting the research hypotheses. The data was analyzed using the SPSS statistical software to examine the strength or weakness of the relationship between the faculty's capabilities and the development of students' critical thinking and problem-solving skills in accordance with the requirements of the twenty-first century.

\subsection{One sample $t$-test.}

Table 2: One Sample $t$-Test

\section{One-Sample T Test}

Test Value $=94.5$ 


\begin{tabular}{|c|c|c|c|c|c|c|}
\hline & \multirow[t]{2}{*}{$\mathrm{t}$} & \multirow{2}{*}{ Df } & \multirow{2}{*}{$\begin{array}{l}\text { Sig. (2- } \\
\text { tailed) }\end{array}$} & \multirow{2}{*}{$\begin{array}{c}\text { Mean } \\
\text { Difference }\end{array}$} & \multicolumn{2}{|c|}{$\begin{array}{l}\text { 95\% Confidence Interval of } \\
\text { the Difference }\end{array}$} \\
\hline & & & & & Lower & Upper \\
\hline Overall Score / 135 & -7.586 & 252 & 0.000 & -9.357 & -11.79 & -6.92 \\
\hline
\end{tabular}

Source: Authors

Table 2 shows a significant relation between higher education programs and students' acquisition of critical thinking and problem solving skills.

Table 3: One Sample T Test by item

\begin{tabular}{|c|c|c|c|c|}
\hline \multicolumn{5}{|c|}{ One Sample T test: Comparison with 3.5 on a 5-points likert scale } \\
\hline Variable & Mean & $\begin{array}{c}\text { Mean } \\
-3.5\end{array}$ & $\begin{array}{l}\text { P-value }(1 \\
\text { tailed })\end{array}$ & Interpretation \\
\hline 1. I have the ability to analyze information. & 3.19 & -0.31 & 0.00 & $\begin{array}{l}\text { P-value }<0.05 \text {, with the } \\
(\text { Mean- } 3.5)<0 \text {, then the } \\
\text { mean is significantly } \\
<3.5\end{array}$ \\
\hline $\begin{array}{l}\text { 2. I have the ability to organize information and } \\
\text { data. }\end{array}$ & 2.97 & -0.53 & 0.00 & $\begin{array}{l}\text { P-value }<0.05 \text {, with the } \\
(\text { Mean- } 3.5)<0 \text {, then the } \\
\text { mean is significantly } \\
<3.5\end{array}$ \\
\hline $\begin{array}{l}\text { 3. I have the ability to notice and appreciate } \\
\text { invisible similarities and differences. }\end{array}$ & 3.12 & -0.38 & 0.00 & $\begin{array}{l}\text { P-value }<0.05 \text {, with the } \\
(\text { Mean- } 3.5)<0 \text {, then the } \\
\text { mean is significantly } \\
<3.5\end{array}$ \\
\hline $\begin{array}{l}\text { 4. I have the ability to analyze other people's } \\
\text { thoughts and understand their views. }\end{array}$ & 3.15 & -0.35 & 0.00 & $\begin{array}{l}\text { P-value }<0.05 \text {, with the } \\
(\text { Mean-3.5) }<0 \text {, then the } \\
\text { mean is significantly } \\
<3.5\end{array}$ \\
\hline $\begin{array}{l}5 . \text { I have the ability to solve problems in innovative } \\
\text { ways. }\end{array}$ & 3.03 & -0.47 & 0.00 & $\begin{array}{l}\text { P-value }<0.05 \text {, with the } \\
(\text { Mean- } 3.5)<0 \text {, then the } \\
\text { mean is significantly } \\
<3.5\end{array}$ \\
\hline $\begin{array}{l}\text { 6. I have the ability to define hypotheses to solve a } \\
\text { problem. }\end{array}$ & 3.16 & -0.34 & 0.00 & $\begin{array}{l}\text { P-value }<0.05 \text {, with the } \\
(\text { Mean-3.5) }<0 \text {, then the } \\
\text { mean is significantly } \\
<3.5\end{array}$ \\
\hline $\begin{array}{l}\text { 7. I have the ability to evaluate and interpret } \\
\text { discussions to determine strengths and weaknesses. }\end{array}$ & 2.98 & -0.52 & 0.00 & $\begin{array}{l}\text { P-value }<0.05 \text {, with the } \\
(\text { Mean-3.5) }<0 \text {, then the } \\
\text { mean is significantly } \\
<3.5\end{array}$ \\
\hline $\begin{array}{l}\text { 8. I have the ability to distinguish the degrees of } \\
\text { possible correctness or error as a result of its } \\
\text { dependence on certain facts. }\end{array}$ & 3.22 & -0.28 & 0.00 & $\begin{array}{l}\text { P-value }<0.05 \text {, with the } \\
(\text { Mean-3.5) }<0 \text {, then the } \\
\text { mean is significantly } \\
<3.5\end{array}$ \\
\hline $\begin{array}{l}\text { 9. The majority agreeing on a particular opinion } \\
\text { does not ensure its validity. }\end{array}$ & 3.14 & -0.36 & 0.00 & $\begin{array}{l}\text { P-value }<0.05 \text {, with the } \\
(\text { Mean- } 3.5)<0 \text {, then the } \\
\text { mean is significantly } \\
<3.5\end{array}$ \\
\hline
\end{tabular}




\begin{tabular}{|c|c|c|c|c|}
\hline $\begin{array}{l}\text { 10. I bear responsibility for the results from my } \\
\text { analysis of the information and data I process. }\end{array}$ & 3.18 & -0.32 & 0.00 & $\begin{array}{l}\text { P-value }<0.05 \text {, with the } \\
(\text { Mean-3.5) }<0 \text {, then the } \\
\text { mean is significantly } \\
<3.5\end{array}$ \\
\hline $\begin{array}{l}\text { 11. I have the ability to use technology to access } \\
\text { required information on time. }\end{array}$ & 3.15 & -0.35 & 0.00 & $\begin{array}{l}\text { P-value }<0.05 \text {, with the } \\
(\text { Mean-3.5) }<0 \text {, then the } \\
\text { mean is significantly } \\
<3.5\end{array}$ \\
\hline $\begin{array}{l}\text { 12. I have the ability to use technology as a tool for } \\
\text { research and organization to communicate } \\
\text { information in the correct and required manner. }\end{array}$ & 3.19 & -0.31 & 0.00 & $\begin{array}{l}\text { P-value }<0.05 \text {, with the } \\
\text { (Mean-3.5) }<0 \text {, then the } \\
\text { mean is significantly } \\
<3.5\end{array}$ \\
\hline $\begin{array}{l}\text { 13. I have the ability to identify sources and } \\
\text { references that serve the research plan I am } \\
\text { working on. }\end{array}$ & 3.18 & -0.32 & 0.00 & $\begin{array}{l}\text { P-value }<0.05 \text {, with the } \\
(\text { Mean-3.5) }<0 \text {, then the } \\
\text { mean is significantly } \\
<3.5\end{array}$ \\
\hline $\begin{array}{l}\text { 14. I have the ability to critique and analyze my } \\
\text { sources. }\end{array}$ & 3.16 & -0.34 & 0.00 & $\begin{array}{l}\text { P-value }<0.05 \text {, with the } \\
\text { (Mean-3.5) }<0 \text {, then the } \\
\text { mean is significantly } \\
<3.5\end{array}$ \\
\hline 15. I have confidence in my scientific findings. & 3.18 & -0.32 & 0.00 & $\begin{array}{l}\text { P-value }<0.05 \text {, with the } \\
(\text { Mean-3.5) }<0 \text {, then the } \\
\text { mean is significantly } \\
<3.5\end{array}$ \\
\hline $\begin{array}{l}\text { 16. I have the ability to be flexible in dealing with } \\
\text { others and accepting others. }\end{array}$ & 3.20 & -0.30 & 0.00 & $\begin{array}{l}\text { P-value }<0.05 \text {, with the } \\
(\text { Mean-3.5) }<0 \text {, then the } \\
\text { mean is significantly } \\
<3.5\end{array}$ \\
\hline 17. I have the ability to accept criticism. & 3.16 & -0.34 & 0.00 & $\begin{array}{l}\text { P-value }<0.05 \text {, with the } \\
(\text { Mean-3.5) }<0 \text {, then the } \\
\text { mean is significantly } \\
<3.5\end{array}$ \\
\hline $\begin{array}{l}\text { 18. I learn from mistakes so that I do not repeat } \\
\text { them. }\end{array}$ & 3.16 & -0.34 & 0.00 & $\begin{array}{l}\text { P-value }<0.05 \text {, with the } \\
(\text { Mean-3.5) }<0 \text {, then the } \\
\text { mean is significantly } \\
<3.5\end{array}$ \\
\hline 19. I face problems smoothly and spontaneously. & 3.24 & -0.26 & 0.00 & $\begin{array}{l}\text { P-value }<0.05 \text {, with the } \\
\text { (Mean-3.5) }<0 \text {, then the } \\
\text { mean is significantly } \\
<3.5\end{array}$ \\
\hline $\begin{array}{l}\text { 20. I have no objection to the change when proven } \\
\text { wrong with convincing evidence. }\end{array}$ & 3.06 & -0.44 & 0.00 & $\begin{array}{l}\text { P-value }<0.05 \text {, with the } \\
(\text { Mean-3.5) }<0 \text {, then the } \\
\text { mean is significantly } \\
<3.5\end{array}$ \\
\hline 21. I have the ability to present new ideas. & 3.23 & -0.27 & 0.01 & $\begin{array}{l}\text { P-value }<0.05 \text {, with the } \\
\text { (Mean-3.5) }<0 \text {, then the } \\
\text { mean is significantly } \\
<3.5\end{array}$ \\
\hline
\end{tabular}




\begin{tabular}{|c|c|c|c|c|}
\hline $\begin{array}{l}\text { 22. I have the ability to come up with new ideas, } \\
\text { discuss them, and explain them to others. }\end{array}$ & 3.10 & -0.40 & 0.00 & $\begin{array}{l}\text { P-value }<0.05 \text {, with the } \\
(\text { Mean- } 3.5)<0 \text {, then the } \\
\text { mean is significantly } \\
<3.5\end{array}$ \\
\hline $\begin{array}{l}\text { 23. I have the ability to respond to new and diverse } \\
\text { perspectives. }\end{array}$ & 3.10 & -0.40 & 0.00 & $\begin{array}{l}\text { P-value }<0.05 \text {, with the } \\
(\text { Mean-3.5) }<0 \text {, then the } \\
\text { mean is significantly } \\
<3.5\end{array}$ \\
\hline $\begin{array}{l}\text { 24. I have the ability to obtain knowledge from its } \\
\text { various sources. }\end{array}$ & 3.16 & -0.34 & 0.00 & $\begin{array}{l}\text { P-value }<0.05 \text {, with the } \\
\text { (Mean-3.5) }<0 \text {, then the } \\
\text { mean is significantly } \\
<3.5\end{array}$ \\
\hline $\begin{array}{l}\text { 25. I have the ability to be independent in } \\
\text { obtaining knowledge. }\end{array}$ & 3.26 & -0.24 & 0.01 & $\begin{array}{l}\text { P-value }<0.05 \text {, with the } \\
(\text { Mean-3.5) }<0 \text {, then the } \\
\text { mean is significantly } \\
<3.5\end{array}$ \\
\hline $\begin{array}{l}\text { 26. I have the ability to use brainstorming with a } \\
\text { team. }\end{array}$ & 3.24 & -0.26 & 0.01 & $\begin{array}{l}\text { P-value }<0.05 \text {, with the } \\
\text { (Mean-3.5) }<0 \text {, then the } \\
\text { mean is significantly } \\
<3.5\end{array}$ \\
\hline $\begin{array}{l}\text { 27. I am curious to know all the new inventions } \\
\text { and innovations. }\end{array}$ & 3.24 & -0.26 & 0.00 & $\begin{array}{l}\text { P-value }<0.05 \text {, with the } \\
(\text { Mean- } 3.5)<0 \text {, then the } \\
\text { mean is significantly } \\
<3.5\end{array}$ \\
\hline
\end{tabular}

Table 3 shows that there exists a statistically significant relationship between higher education programs and students' acquisition of critical thinking and problem solving, because-value $<0.05$ with the (Mean-3.5) $<0$, then the mean is significantly $<3.5$.

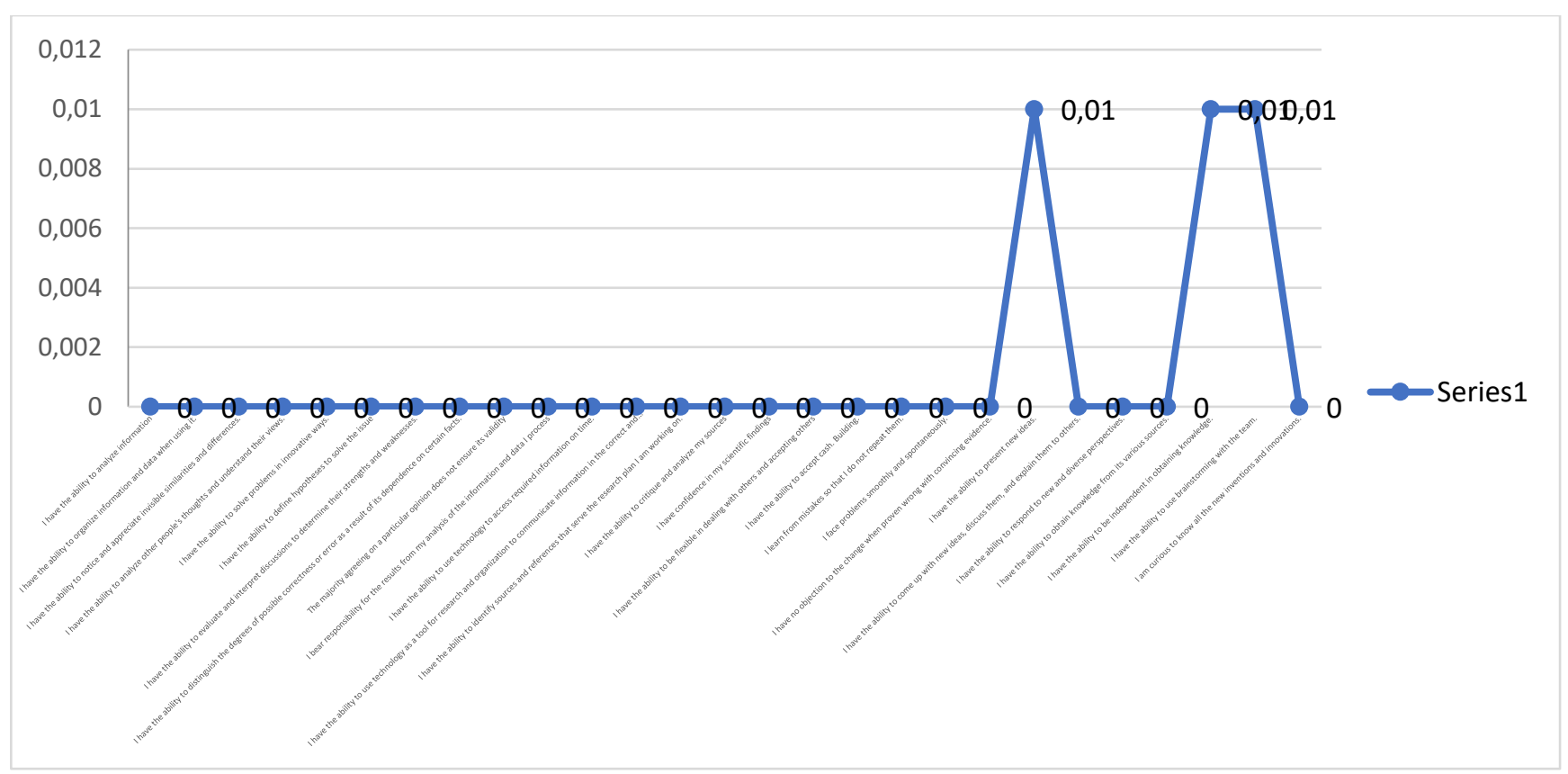

Figure 4: P-Value Comparison 
Figure 4 illustrates the distribution of p-value according to the responses of students. Based on the above and through the preceding statistical results, we can validate the first and the second hypothesis because data analysis showed that there is a statistically significant relationship between higher education programs and students' acquisition of the skill of critical thinking and problem-solving.

\subsection{One sample t- test:}

This test was conducted to determine the P-value in order to accept or reject the first two hypotheses. Table 4 shows that the overall score using the likert scale is 94.5 . The P-value is less than 0.05 . This leads us to accept hypothesis one and two.

Table 4: Comparison of the whole score

\begin{tabular}{|c|c|c|c|c|}
\hline \multicolumn{5}{|c|}{ One Sample T test: Comparison of the Overall Score / 94.5 over 135} \\
\hline Variable & Mean & $\begin{array}{c}\text { Mean - } \\
94.5\end{array}$ & $\begin{array}{c}\text { P-value(1 } \\
\text { tailed) }\end{array}$ & Interpretation \\
\hline Overall Score / 135 & 85.14 & -9.36 & 0.00 & $\begin{array}{l}\text { P-value }<0.05 \text {, with the } \\
\text { (Mean-94.5) }<0 \text {, then the } \\
\text { mean is significantly }<94.5\end{array}$ \\
\hline
\end{tabular}

Source: Authors

Table 5: The relation between different variables

\begin{tabular}{lcccl}
\hline Variable1 & Variable2 & $\begin{array}{c}\text { Test } \\
\text { used }\end{array}$ & $\begin{array}{c}\text { P- } \\
\text { value }\end{array}$ & $\begin{array}{l}\text { Interpretation } \\
\text { Chi }\end{array}$ \\
Pender & Program & $\begin{array}{c}\text { Chuare } \\
\text { squalue }\end{array}$ & $\begin{array}{l}\text { P-value }<05, \text { the relation between the two } \\
\text { variables is significant }\end{array}$ \\
Major & Program & $\begin{array}{c}\text { Chi } \\
\text { square }\end{array}$ & 0.733 & $\begin{array}{l}\text { P-value }>0.05, \text { there is no significant relation } \\
\text { between the two variables }\end{array}$ \\
\hline
\end{tabular}

Source: Authors

Table 5 shows that the relation between gender and program is significant, while it is insignificant between major and program.

\subsection{Means comparison by program.}

Table 6 shows the statistical differences between the answers of students who study in American universities and students who study in Francophone universities, in order to know the impact of higher education programs on students' acquisition of the skills of critical thinking and problem solving as follows:

Table 6: T Test Summary Table

\begin{tabular}{|c|c|c|c|c|}
\hline \multicolumn{5}{|c|}{ Independent Samples T test summary table: Means comparison by Program } \\
\hline Variable & Program & Mean & $\begin{array}{l}\mathrm{P}- \\
\text { value }\end{array}$ & Interpretation \\
\hline \multirow{2}{*}{$\begin{array}{l}\text { 1. I have the ability to } \\
\text { analyze information. }\end{array}$} & American & 3.32 & 0.207 & \multirow{2}{*}{$\begin{array}{l}\text { P-value }>0.05 \text {, there is no significant difference } \\
\text { between the means of the two groups. }\end{array}$} \\
\hline & French & 3.03 & & \\
\hline
\end{tabular}




\begin{tabular}{|c|c|c|c|c|}
\hline \multirow{2}{*}{$\begin{array}{l}\text { 2. I have the ability to } \\
\text { organize information } \\
\text { and data. }\end{array}$} & American & 2.93 & \multirow[t]{2}{*}{0.613} & \multirow{2}{*}{$\begin{array}{l}\text { P-value }>0.05 \text {, there is no significant difference } \\
\text { between the means of the two groups. }\end{array}$} \\
\hline & French & 3.03 & & \\
\hline \multirow{2}{*}{$\begin{array}{l}\text { 3. I have the ability to } \\
\text { notice and appreciate } \\
\text { invisible similarities } \\
\text { and differences. }\end{array}$} & American & 3.11 & \multirow[t]{2}{*}{0.950} & \multirow{2}{*}{$\begin{array}{l}\text { P-value }>0.05 \text {, there is no significant difference } \\
\text { between the means of the two groups. }\end{array}$} \\
\hline & French & 3.12 & & \\
\hline \multirow{2}{*}{$\begin{array}{l}\text { 4. I have the ability to } \\
\text { analyze other people's } \\
\text { thoughts and understand } \\
\text { their views. }\end{array}$} & American & 3.18 & \multirow[t]{2}{*}{0.727} & \multirow{2}{*}{$\begin{array}{l}\text { P-value }>0.05 \text {, there is no significant difference } \\
\text { between the means of the two groups. }\end{array}$} \\
\hline & French & 3.11 & & \\
\hline \multirow{2}{*}{$\begin{array}{l}\text { 5. I have the ability to } \\
\text { solve problems in } \\
\text { innovative ways. }\end{array}$} & American & 3.05 & \multirow[t]{2}{*}{0.826} & \multirow{2}{*}{$\begin{array}{l}\text { P-value }>0.05 \text {, there is no significant difference } \\
\text { between the means of the two groups. }\end{array}$} \\
\hline & French & 3.00 & & \\
\hline \multirow{2}{*}{$\begin{array}{l}\text { 6. I have the ability to } \\
\text { define hypotheses to } \\
\text { solve problems. }\end{array}$} & American & 3.22 & \multirow[t]{2}{*}{0.475} & \multirow{2}{*}{$\begin{array}{l}\text { P-value }>0.05 \text {, there is no significant difference } \\
\text { between the means of the two groups. }\end{array}$} \\
\hline & French & 3.08 & & \\
\hline \multirow{2}{*}{$\begin{array}{l}\text { 7. I have the ability to } \\
\text { evaluate and interpret } \\
\text { discussions ro to } \\
\text { determine strengths and } \\
\text { weaknesses. }\end{array}$} & American & 2.91 & \multirow[t]{2}{*}{0.480} & \multirow{2}{*}{$\begin{array}{l}\text { P-value }>0.05 \text {, there is no significant difference } \\
\text { between the means of the two groups. }\end{array}$} \\
\hline & French & 3.06 & & \\
\hline \multirow[b]{2}{*}{$\begin{array}{l}\text { 8. I have the ability to } \\
\text { distinguish the degrees } \\
\text { of possible correctness } \\
\text { or error as a result of its } \\
\text { dependence on certain } \\
\text { facts. }\end{array}$} & American & 3.13 & \multirow[t]{2}{*}{0.376} & \multirow{2}{*}{$\begin{array}{l}\text { P-value }>0.05 \text {, there is no significant difference } \\
\text { between the means of the two groups. }\end{array}$} \\
\hline & French & 3.32 & & \\
\hline \multirow{2}{*}{$\begin{array}{l}\text { 9. The majority } \\
\text { agreeing on a particular } \\
\text { opinion does not ensure } \\
\text { its validity. }\end{array}$} & American & 3.22 & \multirow[t]{2}{*}{0.441} & \multirow{2}{*}{$\begin{array}{l}\text { P-value }>0.05 \text {, there is no significant difference } \\
\text { between the means of the two groups. }\end{array}$} \\
\hline & French & 3.05 & & \\
\hline \multirow{2}{*}{$\begin{array}{l}\text { 10. I bear responsibility } \\
\text { for the results from my } \\
\text { analysis of the } \\
\text { information and data I } \\
\text { process. }\end{array}$} & American & 3.26 & \multirow[t]{2}{*}{0.422} & \multirow{2}{*}{$\begin{array}{l}\text { P-value }>0.05 \text {, there is no significant difference } \\
\text { between the means of the two groups. }\end{array}$} \\
\hline & French & 3.08 & & \\
\hline 11. I have the ability to & American & 3.22 & \multirow[t]{3}{*}{0.451} & \multirow{3}{*}{$\begin{array}{l}\text { P-value }>0.05 \text {, there is no significant difference } \\
\text { between the means of the two groups. }\end{array}$} \\
\hline $\begin{array}{lr}\text { use } & \text { technology to } \\
\text { access } & \text { required }\end{array}$ & French & 3.06 & & \\
\hline \multirow{2}{*}{$\begin{array}{l}\text { information on time. } \\
\text { 12. I have the ability to } \\
\text { use technology as a tool }\end{array}$} & American & 3.28 & & \\
\hline & French & 3.08 & \multirow{3}{*}{0.347} & \multirow{3}{*}{$\begin{array}{l}\text { P-value }>0.05 \text {, there is no significant difference } \\
\text { between the means of the two groups. }\end{array}$} \\
\hline $\begin{array}{lr}\text { for research and } \\
\text { organization } \\
\text { communicate }\end{array}$ & & & & \\
\hline $\begin{array}{l}\text { information in the } \\
\text { correct and required } \\
\text { manner. }\end{array}$ & & & & \\
\hline 13. I have the ability to & American & 3.30 & 0.181 & P-value $>0.05$, there is no significant difference \\
\hline $\begin{array}{l}\text { identify sources and } \\
\text { references that serve the }\end{array}$ & French & 3.02 & & \\
\hline $\begin{array}{l}\text { research plan I am } \\
\text { working on. }\end{array}$ & & & & \\
\hline 14. I have the ability to & American & 3.44 & 0.001 & $\mathrm{P}$-value $<0.05$, the difference between the means \\
\hline $\begin{array}{l}\text { critique and analyze my } \\
\text { sources }\end{array}$ & French & 2.80 & & of the two groups is significant \\
\hline 15. I have confidence in & American & 3.26 & 0.447 & P-value $>0.05$, there is no significant difference \\
\hline
\end{tabular}




\begin{tabular}{|c|c|c|c|c|}
\hline my scientific findings & French & 3.09 & & between the means of the two groups. \\
\hline \multirow{2}{*}{$\begin{array}{l}\text { 16. I have the ability to } \\
\text { be flexible in dealing } \\
\text { with others and } \\
\text { accepting others }\end{array}$} & American & 3.34 & \multirow[t]{2}{*}{0.136} & \multirow{2}{*}{$\begin{array}{l}\text { P-value }>0.05 \text {, there is no significant difference } \\
\text { between the means of the two groups. }\end{array}$} \\
\hline & French & 3.03 & & \\
\hline \multirow{2}{*}{$\begin{array}{l}\text { 17. I have the ability to } \\
\text { accept criticism. }\end{array}$} & American & 3.17 & \multirow[t]{2}{*}{0.875} & \multirow{2}{*}{$\begin{array}{l}\text { P-value }>0.05 \text {, there is no significant difference } \\
\text { between the means of the two groups. }\end{array}$} \\
\hline & French & 3.14 & & \\
\hline \multirow{2}{*}{$\begin{array}{l}\text { 18. I learn from } \\
\text { mistakes so that I do not } \\
\text { repeat them. }\end{array}$} & American & 3.16 & \multirow[t]{2}{*}{0.963} & \multirow{2}{*}{$\begin{array}{l}\text { P-value }>0.05 \text {, there is no significant difference } \\
\text { between the means of the two groups. }\end{array}$} \\
\hline & French & 3.17 & & \\
\hline \multirow{2}{*}{$\begin{array}{l}\text { 19. I face problems } \\
\text { smoothly } \\
\text { spontaneously. }\end{array}$} & American & 3.28 & \multirow[t]{2}{*}{0.636} & \multirow{2}{*}{$\begin{array}{l}\text { P-value }>0.05 \text {, there is no significant difference } \\
\text { between the means of the two groups. }\end{array}$} \\
\hline & French & 3.18 & & \\
\hline \multirow{4}{*}{$\begin{array}{l}\text { 20. I have no objection } \\
\text { to the change when } \\
\text { proven wrong with } \\
\text { convincing evidence. } \\
\text { 21. I have the ability to } \\
\text { present new ideas. }\end{array}$} & American & 3.04 & \multirow[t]{2}{*}{0.806} & \multirow{2}{*}{$\begin{array}{l}\text { P-value }>0.05 \text {, there is no significant difference } \\
\text { between the means of the two groups. }\end{array}$} \\
\hline & French & 3.09 & & \\
\hline & American & 3.35 & \multirow[t]{2}{*}{0.208} & \multirow{2}{*}{$\begin{array}{l}\text { P-value }>0.05 \text {, there is no significant difference } \\
\text { between the means of the two groups. }\end{array}$} \\
\hline & French & 3.08 & & \\
\hline \multirow{3}{*}{$\begin{array}{l}\text { 22. I have the ability to } \\
\text { come up with new } \\
\text { ideas, discuss them, and } \\
\text { explain them to others. }\end{array}$} & American & 3.26 & \multirow[t]{2}{*}{0.068} & \multirow{2}{*}{$\begin{array}{l}\text { P-value }>0.05 \text {, there is no significant difference } \\
\text { between the means of the two groups. }\end{array}$} \\
\hline & French & 2.89 & & \\
\hline & American & 2.93 & \multirow[t]{2}{*}{0.059} & \multirow{2}{*}{$\begin{array}{l}\text { P-value }>0.05 \text {, there is no significant difference } \\
\text { between the means of the two groups. }\end{array}$} \\
\hline $\begin{array}{l}23 \text {. I have the ability to } \\
\text { respond to new and } \\
\text { diverse perspectives. }\end{array}$ & French & 3.32 & & \\
\hline \multirow{2}{*}{$\begin{array}{l}\text { 24. I have the ability to } \\
\text { obtain knowledge from } \\
\text { its various sources. }\end{array}$} & American & 3.04 & \multirow[t]{2}{*}{0.201} & \multirow{2}{*}{$\begin{array}{l}\text { P-value }>0.05 \text {, there is no significant difference } \\
\text { between the means of the two groups. }\end{array}$} \\
\hline & French & 3.32 & & \\
\hline \multirow{2}{*}{$\begin{array}{l}25 . \text { I have the ability to } \\
\text { be independent in } \\
\text { obtaining knowledge. }\end{array}$} & American & 3.44 & \multirow[t]{2}{*}{0.048} & \multirow{2}{*}{$\begin{array}{l}\text { P-value }<0.05 \text {, the difference between the means } \\
\text { of the two groups is significant }\end{array}$} \\
\hline & French & 3.03 & & \\
\hline \multirow{2}{*}{$\begin{array}{l}\text { 26. I have the ability to } \\
\text { use brainstorming with } \\
\text { a team. }\end{array}$} & American & 3.34 & \multirow[t]{2}{*}{0.270} & \multirow{2}{*}{$\begin{array}{l}\text { P-value }>0.05 \text {, there is no significant difference } \\
\text { between the means of the two groups. }\end{array}$} \\
\hline & French & 3.11 & & \\
\hline \multirow{4}{*}{$\begin{array}{l}\text { 27. I am curious to } \\
\text { know all the new } \\
\text { inventions } \\
\text { innovations. } \\
\text { Overall Score / } 135\end{array}$} & American & 3.22 & 0.756 & value $>0.05$, there is no significant difference \\
\hline & French & 3.28 & & \\
\hline & American & 86.39 & 0.257 & $P$-value $>0.05$, there is no significant difference \\
\hline & French & 83.57 & & \\
\hline
\end{tabular}

Source: Authors

Table 6 shows that there is a statistically significant difference between students 'answers to item 14 which is related to having the ability to criticize and analyze sources as the average of responses among students who learn in schools that follow the American system is (3.44) with a degree of approval (average). This means that they have a higher ability than students who are learning in Francophone universities in the analysis and critique of information, as the rate for students of the French system (2.80) with a degree of approval (medium), but the difference was due to:

P-value $<0.05$, the difference between the means of the two groups is significant. ( $\mathrm{Sig}=0.01$ $<\alpha=0.05$.) 
Table 6 also shows that there is a statistically significant difference between students 'answers to the twenty-fifth item which expresses the ability of students to obtain the information they want independently, relying on their own ability to obtain knowledge. The average of answers among students who learn in universities that follow the American system is (3.44), and this means that their ability to obtain knowledge independently is higher than students who follow the French system, as the rate for students of French systems reached (3.03) with an average degree. Therefore, the differences with the statistical function were the result of:

$\mathrm{P}$-value $<0.05$, the difference between the means of the two groups is significant. ( $\mathrm{Sig}=0.048$ $<\alpha=0.05)$. This indicates that our second hypothesis is valid.

\subsection{Means comparison by gender.}

Table 7 shows the relation between students' acquisition of critical thinking and problem solving skills with respect to their gender.

Table 7: Comparison by Gender

\begin{tabular}{|c|c|c|c|c|}
\hline \multicolumn{5}{|c|}{ Independent Samples T test summary table: Means comparison by Gender(Significant Results table) } \\
\hline Variable & Gender & Mean & $\begin{array}{l}\mathrm{P}- \\
\text { value }\end{array}$ & Interpretation \\
\hline \multirow{2}{*}{$\begin{array}{l}\text { 6. I have the ability to } \\
\text { define hypotheses to } \\
\text { solve the issue. }\end{array}$} & Female & 3.35 & \multirow[b]{2}{*}{0.047} & \multirow{2}{*}{$\begin{array}{l}\text { P-value }<0.05 \text {, the difference between the means } \\
\text { of the two groups is significant }\end{array}$} \\
\hline & Male & 2.96 & & \\
\hline \multirow{2}{*}{$\begin{array}{l}\text { 7. I have the ability to } \\
\text { evaluate and interpret } \\
\text { discussions to determine } \\
\text { strengths and } \\
\text { weaknesses. }\end{array}$} & Female & 3.23 & \multirow[b]{2}{*}{0.014} & \multirow[b]{2}{*}{$\begin{array}{l}\text { P-value }<0.05 \text {, the difference between the means } \\
\text { of the two groups is significant }\end{array}$} \\
\hline & Male & 2.73 & & \\
\hline \multirow[b]{2}{*}{$\begin{array}{l}\text { 12. I have the ability to } \\
\text { use technology as a tool } \\
\text { for research and } \\
\text { organization to } \\
\text { communicate } \\
\text { information in the } \\
\text { correct and required } \\
\text { manner. }\end{array}$} & Female & 3.43 & & \multirow[b]{2}{*}{$\begin{array}{l}\text { P-value }<0.05 \text {, the difference between the means } \\
\text { of the two groups is significant }\end{array}$} \\
\hline & Male & 2.95 & 0.023 & \\
\hline \multirow{2}{*}{$\begin{array}{l}\text { 16. I have the ability to } \\
\text { be flexible in dealing } \\
\text { with others and } \\
\text { accepting others. }\end{array}$} & Female & 2.99 & \multirow[b]{2}{*}{0.034} & \multirow[b]{2}{*}{$\begin{array}{l}\text { P-value }<0.05 \text {, the difference between the means } \\
\text { of the two groups is significant }\end{array}$} \\
\hline & Male & 3.42 & & \\
\hline \multirow{2}{*}{$\begin{array}{l}\text { 20. I have no objection } \\
\text { to the change when } \\
\text { proven wrong with } \\
\text { convincing evidence. }\end{array}$} & Female & 3.35 & \multirow[b]{2}{*}{0.009} & \multirow[b]{2}{*}{$\begin{array}{l}\text { P-value }<0.05 \text {, the difference between the means } \\
\text { of the two groups is significant }\end{array}$} \\
\hline & Male & 2.77 & & \\
\hline \multirow{2}{*}{$\begin{array}{l}\text { 22. I have the ability to } \\
\text { come up with new } \\
\text { ideas, discuss them, and }\end{array}$} & Female & 3.41 & \multirow[b]{2}{*}{0.001} & \multirow{2}{*}{$\begin{array}{l}\text { P-value }<0.05 \text {, the difference between the means } \\
\text { of the two groups is significant }\end{array}$} \\
\hline & Male & 2.78 & & \\
\hline
\end{tabular}




\begin{tabular}{|c|c|c|c|c|}
\hline explain them to others. & & & & \\
\hline \multirow{2}{*}{$\begin{array}{l}\text { 24. I have the ability to } \\
\text { obtain knowledge from } \\
\text { its various sources. }\end{array}$} & Female & 3.50 & \multirow{2}{*}{0.002} & \multirow{2}{*}{$\begin{array}{l}\text { P-value }<0.05 \text {, the difference between the means } \\
\text { of the two groups is significant }\end{array}$} \\
\hline & Male & 2.82 & & \\
\hline \multirow{2}{*}{$\begin{array}{l}\text { 25. I have the ability to } \\
\text { be independent in } \\
\text { obtaining knowledge. }\end{array}$} & Female & 3.76 & \multirow{2}{*}{0.000} & \multirow{2}{*}{$\begin{array}{l}\text { P-value }<0.05 \text {, the difference between the means } \\
\text { of the two groups is significant }\end{array}$} \\
\hline & Male & 2.75 & & \\
\hline \multirow{2}{*}{$\begin{array}{l}\text { 26. I have the ability to } \\
\text { use brainstorming with } \\
\text { a team. }\end{array}$} & Female & 3.49 & \multirow[b]{2}{*}{0.017} & \multirow{2}{*}{$\begin{array}{l}\text { P-value }<0.05 \text {, the difference between the means } \\
\text { of the two groups is significant }\end{array}$} \\
\hline & Male & 2.99 & & \\
\hline \multirow{2}{*}{$\begin{array}{l}\text { 27. I am curious to } \\
\text { know all the new } \\
\text { inventions } \\
\text { innovations. }\end{array}$} & Female & 3.59 & \multirow[b]{2}{*}{0.000} & \multirow[b]{2}{*}{$\begin{array}{l}\text { P-value }<0.05 \text {, the difference between the means } \\
\text { of the two groups is significant }\end{array}$} \\
\hline & Male & 2.89 & & \\
\hline \multirow{2}{*}{ Overall Score / 135} & Female & 88.35 & \multirow{2}{*}{0.008} & \multirow{2}{*}{$\begin{array}{l}\text { P-value }<0.05 \text {, the difference between the means } \\
\text { of the two groups is significant }\end{array}$} \\
\hline & Male & 81.89 & & \\
\hline
\end{tabular}

Table 7 shows that there are statistically significant differences between students' answers in the two groups of universities with respect to their gender, as all answers were less than sig $\alpha$ $=0.05$.

\subsection{Means comparison by major.}

Table 8 shows the relation between students' answers and their majors.

Table 8: Comparison by major

\begin{tabular}{|c|c|c|c|c|}
\hline \multicolumn{5}{|c|}{ Independent Samples T test summary table: Means comparison by Major(Significant Results table) } \\
\hline Variable & Major & Mean & $\begin{array}{l}\mathrm{P} \text { - } \\
\text { value }\end{array}$ & Interpretation \\
\hline \multirow[b]{2}{*}{$\begin{array}{l}\text { 5. I have the ability to } \\
\text { solve problems in } \\
\text { innovative ways. }\end{array}$} & Marketing & 2.50 & \multirow[b]{2}{*}{0.000} & \multirow[b]{2}{*}{$\begin{array}{l}\text { P-value }<0.05 \text {, the difference between the } \\
\text { means of the two groups is significant }\end{array}$} \\
\hline & $\begin{array}{l}\text { Management } \\
\text { Information } \\
\text { System }\end{array}$ & 3.35 & & \\
\hline \multirow{2}{*}{$\begin{array}{l}\text { 8. I have the ability to } \\
\text { distinguish the } \\
\text { degrees of possible } \\
\text { correctness or error as } \\
\text { a result of its } \\
\text { dependence on certain } \\
\text { facts. }\end{array}$} & $\begin{array}{l}\text { Financial } \\
\text { Management }\end{array}$ & 2.95 & \multirow[b]{2}{*}{0.043} & \multirow[b]{2}{*}{$\begin{array}{l}\text { P-value }<0.05 \text {, the difference between the } \\
\text { means of the two groups is significant }\end{array}$} \\
\hline & Accounting & 3.38 & & \\
\hline \multirow[b]{2}{*}{$\begin{array}{l}\text { 15. I have confidence } \\
\text { in my scientific } \\
\text { findings. }\end{array}$} & Marketing & 3.68 & \multirow[b]{2}{*}{0.000} & \multirow[b]{2}{*}{$\begin{array}{l}\text { P-value }<0.05 \text {, the difference between the } \\
\text { means of the two groups is significant }\end{array}$} \\
\hline & $\begin{array}{l}\text { Management } \\
\text { Information } \\
\text { System }\end{array}$ & 2.88 & & \\
\hline \multirow{2}{*}{$\begin{array}{l}\text { 18. I learn from } \\
\text { mistakes so that I do } \\
\text { not repeat them. }\end{array}$} & $\begin{array}{l}\text { Financial } \\
\text { Management }\end{array}$ & 3.50 & \multirow[t]{2}{*}{0.019} & \multirow{2}{*}{$\begin{array}{l}\text { P-value }<0.05 \text {, the difference between the } \\
\text { means of the two groups is significant }\end{array}$} \\
\hline & Accounting & 2.96 & & \\
\hline 21. I have the ability & Marketing & 2.89 & 0.014 & P-value $<0.05$, the difference between the \\
\hline
\end{tabular}




\begin{tabular}{|c|c|c|c|c|}
\hline to present new ideas. & $\begin{array}{l}\text { Management } \\
\text { Information } \\
\text { System }\end{array}$ & 3.44 & & means of the two groups is significant \\
\hline \multirow{2}{*}{$\begin{array}{l}\text { 22. I have the ability } \\
\text { to come up with new } \\
\text { ideas, discuss them, } \\
\text { and explain them to } \\
\text { others. }\end{array}$} & $\begin{array}{l}\text { Financial } \\
\text { Management }\end{array}$ & 2.84 & \multirow{2}{*}{0.042} & \multirow{2}{*}{$\begin{array}{l}\text { P-value }<0.05 \text {, the difference between the } \\
\text { means of the two groups is significant }\end{array}$} \\
\hline & Accounting & 3.25 & & \\
\hline \multirow{2}{*}{$\begin{array}{l}\text { 24. I have the ability } \\
\text { to obtain knowledge } \\
\text { from its various } \\
\text { sources. }\end{array}$} & Marketing & 2.68 & \multirow[b]{2}{*}{0.000} & \multirow[b]{2}{*}{$\begin{array}{l}\mathrm{P} \text {-value }<0.05, \text { the difference between the } \\
\text { means of the two groups is significant }\end{array}$} \\
\hline & $\begin{array}{l}\text { Management } \\
\text { Information } \\
\text { System } \\
\end{array}$ & 3.46 & & \\
\hline \multirow{2}{*}{$\begin{array}{l}25 \text {. I have the ability } \\
\text { to be independent in } \\
\text { obtaining knowledge. }\end{array}$} & $\begin{array}{l}\text { Financial } \\
\text { Management }\end{array}$ & 2.79 & \multirow{2}{*}{0.000} & \multirow{2}{*}{$\begin{array}{l}\text { P-value }<0.05 \text {, the difference between the } \\
\text { means of the two groups is significant }\end{array}$} \\
\hline & Accounting & 3.55 & & \\
\hline \multirow[b]{2}{*}{$\begin{array}{l}\text { 26. I have the ability } \\
\text { to use brainstorming } \\
\text { with the team. }\end{array}$} & Marketing & 2.93 & \multirow[b]{2}{*}{0.020} & \multirow[b]{2}{*}{$\begin{array}{l}\mathrm{P} \text {-value }<0.05 \text {, the difference between the } \\
\text { means of the two groups is significant }\end{array}$} \\
\hline & $\begin{array}{l}\text { Management } \\
\text { Information } \\
\text { System } \\
\end{array}$ & 3.43 & & \\
\hline
\end{tabular}

Table 8 indicates that there is a statistically significant relationship between students 'answers concerning their university majors, and the highest rate (3.68) reached a degree of (strong) approval for the answers of students registered in the major of the educational management, while the minimum rate (2.50) reached a degree of approval (average) for the answers of students registered in the major of administration.

\section{Conclusion and Suggestion}

Higher education plays an important role in controlling the emerging crises that may strike countries, by developing its curricula in a manner that is commensurate with the changes and developments taking place in our world, especially in terms of diseases, serious epidemics, and widespread cross-border and continent-transmitted epidemics that become epidemics. What is happening nowadays in terms of the Covid-19 crisis has made it clear that we need updated curricula and higher education programs to help us face the upcoming situations. Out of a sudden, teachers and students had to deal with a new system of teaching and learning. Although general knowledge is required in different aspects of life, critical thinking, and problem-solving skills are being paramount these days. Such abilities help us know what to do in emergencies and critical situations.

There may exist a lack in critical thinking teaching because teachers sometimes prioritize academic material over life skills (Bean, 2011). This is controversial because we cannot think critically about something we do not know well, and at the same time, we need the critical thinking skill to be able to process and confront emerging situations. Our findings revealed a significant correlation between university programs and critical thinking and problem solving skills. Haber (2020) recommends teaching these skills explicitly by adding specific practices to the curriculum starting from pre-school. In this way, higher education teachers will not feel 
overwhelmed by new demands because these skills would be ingrained in students' mentalities and attitudes throughout the educational journey. We must learn how to rethink the general educational process and programs based on the recognition that the majority of the wrong things that happened in this world came as a result of sticking to traditional practices. Going forward with this type of education will only contribute to exacerbating our problems because the feasibility of it today must be measured according to new standards, which are arming students and people in general with the knowledge, skills, and abilities to know how deal with the continuous change.

\section{Conflict of Interest}

The authors of the article declare no conflict of interest.

\section{Funding}

This research study was not funded by any institution. The authors conducted the study on their own expenses.

\section{References}

Bayer, D., \& Morrison, I. (1988). Standard bases and geometric invariant theory I. Initial ideals and state polytopes. J. Symb. Comput., 6(2/3), 209-217.

Bean, J. C. (2011). Engaging ideas: The professor's guide to integrating writing, critical thinking, and active learning in the classroom. John Wiley \& Sons.

Beilin, H., \&Pufall, P. B. (Eds.). (2013). Piaget's theory: prospects and possibilities. Psychology Press.

Boud, D., \& Hager, P. (2012).Re-thinking continuing professional development through changing metaphors and location in professional practices. Studies in continuing education, 34(1), 17-30.

Bowen, W. G., Kurzweil, M. A., Tobin, E. M., \&Pichler, S. C. (2005). Equity and excellence in American higher education.University of Virginia Press.

Carver, C. S., \&Scheier, M. F. (2012). Attention and self-regulation: A control-theory approach to human behavior. Springer Science \& Business Media.

Dörnyei, Z. (2003). Attitudes, orientations, and motivations in language learning: Advances in theory, research, and applications. Language learning, 53(S1), 3-32.

Edgar, D. W. (2012). Learning theories and historical events affecting instructional design in education: Recitation literacy toward extraction literacy practices. Sage Open, 2(4), 2158244012462707.

Ennis, R. H. (1993). Critical thinking assessment. Theory into practice, 32(3), 179-186.

Facione, P. A. (2011). Critical thinking: What it is and why it counts. Insight assessment, 2007(1), 1-23.

Gay, L. R. (2012). Educational research: competencies for analysis and applications $\left(10^{\text {th }}\right.$ edition). United States of America. Pearson Education 
Gordon, E. E. (2013). Future jobs: Solving the employment and skills crisis: Solving the employment and skills crisis. ABC-CLIO.

Haber, J. (2020). Critical Thinking. MIT Press.

Koske, I., Wanner, I., Bitetti, R., \&Barbiero, O. (2015). The 2013 update of the OECD's database on product market regulation: Policy insights for OECD and non-OECD countries.

Negrini, L. S. (2018). Handbook Of Attachment: Theory, Research, And Clinical Applications Jude Cassidy and Phillip R. Shaver (Eds.), New York: Guilford Press, 2016, 1,068 pp., ISBN 978-1-4625-2529-4. Infant Mental Health Journal, 39(5), 618620.

Schleicher, A. (2012). Preparing teachers and developing school leaders for the 21st century: Lessons from around the world. OECD Publishing. 2, rue Andre Pascal, F75775 Paris Cedex 16, and France.

Seaman, M. (2011). Bloom's Taxonomy. Curriculum \& Teaching Dialogue, 13.

Stoddard, S. T., Forshey, B. M., Morrison, A. C., Paz-Soldan, V. A., Vazquez-Prokopec, G. M., Astete, H., \&Kochel, T. J. (2013). House-to-house human movement drives dengue virus transmission. Proceedings of the National Academy of Sciences, 110(3), 994-999.

Trilling, B., \&Fadel, C. (2009). 21 st century skills: Learning for life in our times. John Wiley $\&$ Sons. 